\section{Bits and pieces of science policy}

\section{Robert Walgate}

The European Scientific Community. By Ros Herman. Longman: 1986. Pp.201. 118.50. Longman appear not to know whether this book is available in the United States.

From 1550 to 1850 , science was a European affair. Now, more or less, it is American. Why? Ros Herman, the senior writer on science policy for New Scientist, immediately places a simple, nagging question in the reader's mind with the first words of her book; but the question remains unanswered, though it hovers over every page.

Not that Ms Herman explicitly attempts to answer her question. Her book, as she writes later, aims to provide a backdrop, a catalogue and interpretation of the myriad national and international institutions which are involved in the government of European science. She looks at budgets, manpower, policy-making structures and policies throughout Europe, and sets them in a historical perspective. In the end, she succeeds in charting the maze of faint crossing and parallel tracks along which European science lost its preeminence.

Of course, European science is not dead; its decline is only relative, and there are isolated areas where Europe continues to lead (usually because of extraordinary drive on the part of an individual scientist). However, we need to explain why European papers now make up only a small part of the research published in leading journals. On p.13 of her book, Ms Herman quotes Vannevar Bush, speaking in the United States in 1945:

We can no longer count on a ravaged Europe as a source of fundamental knowledge. In the past we have devoted much of our best efforts to the application of such knowledge which has been discovered abroad. In the future we must pay increased attention to discovering this knowledge for ourselves.

Is the resolution implicit in this remark what led to American greatness in science, and relative European decline? (And, if so, what about the Japanese, who say much the same thing today?) It was not necessary for European science to decline per se: the great explosion of American science simply, bit by bit, began to shift the glory, the important discoveries, the prizes across the Atlantic.

There were - and are - special circumstances in the United States. By 1945 the American scientific community had been swelled by the wartime flood of European émigrés (not long ago, for example, it was possible to trace all the lead- ing high-energy physics groups in the United States back to Fermi and his pupils). The open, meritocratic and competitive society encouraged science of the same character. With its own firm science base, leavened by the wisdom of the émigrés, with the determination of people like Mr Bush (and the money that followed) and with a mobile society of a couple of hundred million souls, America was set fair.

The European "answer", after a savage nationalistic war, was to set up multitudinous, national science planning and policy bodies, scattered over the continent (and Britain). Everyone knew that "science had won the war", that science was important. The trouble was that Europe was and remains - in comparatively small pieces, with a British science policy, and a French science policy and so on down even to a Finnish science policy (in a country with half the population of Greater London, as Ms Herman points out). Europe still had (and has) the talent, but it lacked (and lacks) the structures through which to exploit that talent at anything like the same rate as America.

There have been exceptions. The European Organization for Nuclear Research (CERN), for example, and the European Space Agency (ESA), responsible for the recent Giotto-Halley encounter. CERN

\section{Academic matters}

\section{Alec Merrison}

Government and the Universities in Britain: Programme and Performance 19601980. By John Carswell. Cambridge University Press:1986. Pp.181. £19.50, $\$ 42.50$.

THE subject of Government and the Universities in Britain could hardly be more important, even within the restricted canvas implied by John Carswell's subtitle. But the reader will look in vain to this slackly conceived and carelessly executed book for a serious analysis of what has happened over the past 20 years, or for guidance for the future.

$\mathrm{Mr}$ Carswell is, of course, unlucky in his timing, because he does not "attempt to describe events after 1978 when [his] direct experience of university - state relations came to an end"; so much of critical importance has happened since then that his book inevitably has a somewhat otherworldly air. Even so, it is an uneasy mixture of description and analysis of serious matters with personal reminiscence. I really do not think, for example, that the reader will be enlightened being told that Sir Maurice Dean, Joint Permanent Under-Secretary at the Department of Education and Science 1963-1964, was began early in the $1950 \mathrm{~s}$ as a theoretical group at the Niels Bohr Institute in Copenhagen. But even CERN took 30 years to win its first Nobel prizes, arguably because of a European disinclination to take risks. Moreover to take CERN as a model - for the European Molecular Biology Laboratory, for example - was a mistake, for high-energy physics is a very special case, in its need for enormous central machinery that simply had to be pooled to be built at all. ESA is a comparative upstart. Today it looks very healthy by comparison with the US National Aeronautics and Space Administration, but there have been many false dawns for European space industries since 1945.

It could just be that after 40 years European science is beginning to get moving. But while there is a new awareness of the need for a continental scale in science and technology, nothing will change very much until there is central European peer review and competition for funds, and total mobility of scientific labour. Until that happens, the United States and then, perhaps, Japan, will always have the edge over an old continent whose patchwork science policies Ms Herman has so ably documented.

Robert Walgate is France correspondent for Nature.

fond of flashing his bright red braces

So what would one look for in a book with this title? Without the subtitle - and even with it - certainly some discussion of what functions a university cannot cede to the state without losing its autonomy; indeed, discussion too of whether universities like those in Great Britain, with so much of their income coming directly from public funds, can genuinely claim to be autonomous at all. And, again, examination of the question whether universities should enjoy autonomy and selfgovernment if they have already grabbed the Queen's shilling. Should they not be directed by democratically elected representatives and all that?

The argument for the universities' independence, as for all free institutions within the state, is the strength and flexibility this ultimately gives to the society in which they have their being. As it happens, we are, I think, particularly good in Britain at using this kind of freedom wisely, but the whole edifice depends upon convention. Universities do have their Royal Charters, but all that could be overturned in the twinkling of an eye.

In a book of this kind one would also look for an extensive and thorough account of the means of government funding other than that of the University Grants Committee (UGC), in particular that of the Research Councils. A "contrast and compare" of the block grant, blanket-style 